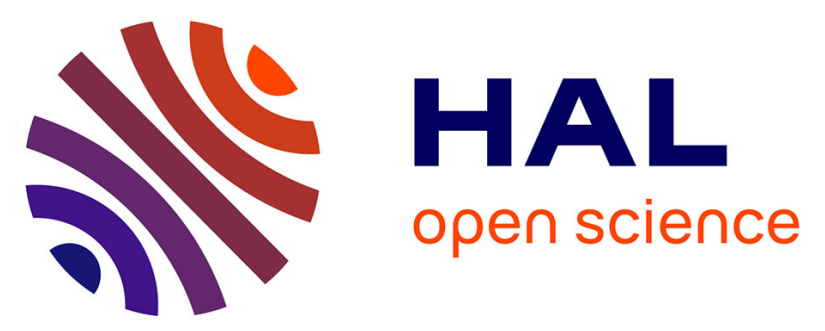

\title{
Exposure assessment model to combine thermal inactivation (log reduction) and thermal injury (heat-treated spore lag time) effects on non-proteolytic Clostridium botulinum
}

Jeanne Marie J. M. Membré, E. Wemmenhove, P. J. Mcclure

\section{To cite this version:}

Jeanne Marie J. M. Membré, E. Wemmenhove, P. J. Mcclure. Exposure assessment model to combine thermal inactivation (log reduction) and thermal injury (heat-treated spore lag time) effects on non-proteolytic Clostridium botulinum. Safety, reliability and risk analysis: theory, methods and applications, 3, CRC Press (Taylor

Francis Group), 2009, 978-0-415-48513-5. hal-02811614

\section{HAL Id: hal-02811614 \\ https://hal.inrae.fr/hal-02811614}

Submitted on 6 Jun 2020

HAL is a multi-disciplinary open access archive for the deposit and dissemination of scientific research documents, whether they are published or not. The documents may come from teaching and research institutions in France or abroad, or from public or private research centers.
L'archive ouverte pluridisciplinaire HAL, est destinée au dépôt et à la diffusion de documents scientifiques de niveau recherche, publiés ou non, émanant des établissements d'enseignement et de recherche français ou étrangers, des laboratoires publics ou privés. 
In Safety, reliability and risk analysis: theory, methods and applications. S. Martorell, C.G. Soares, J. Barnett (eds).

2009. Volume 3, pp 2295-2303. Publisher: CRC Press, Taylor and Francis Group, London. ISBN 978-0-415-48513-5

\title{
Exposure assessment model to combine thermal inactivation (log reduction) and thermal injury (heat-treated spore lag time) effects on non-proteolytic Clostridium botulinum
}

\author{
Jeanne-Marie Membré, Ellen Wemmenhove \& Peter McClure \\ Unilever - Safety \& Environmental Assurance Centre. Colworth Park. Sharnbrook MK44 1LQ. UK
}

\begin{abstract}
Clostridium botulinum is one of the most severe hazards causing foodborne disease. There are well-established control procedures that have been identified to destroy or inhibit growth of nonproteolytic Clostridium botulinum spores. One of these used in the manufacture of chilled foods is application of the 'non-proteolytic $C$. botulinum cook', based on the characteristic that spores of non-proteolytic strains are considerably more heat sensitive than spores of proteolytic strains. It is generally agreed that a temperature of $90^{\circ} \mathrm{C}$ for $10 \mathrm{~min}$ will deliver a $6 \mathrm{D}$ inactivation of non-proteolytic $C$. botulinum and this is a commonly used performance standard for the heat processing of chilled foods. However, under stress conditions provided by intrinsic (e.g. pH) or extrinsic factors (e.g. storage at chilled temperatures), heat-treated surviving spores need a certain time (namely lag time) before recovering from injury, germinating and then starting to grow. The objective of this work was to explore the possibility of identifying milder heat-treatments than 10 minutes at $90^{\circ} \mathrm{C}$, by incorporating this lag time with the 'traditional' thermal inactivation effect. To do so, an exposure assessment model, based on the Degree of Protection (DoP) concept was developed. Results are promising; for example, with a product having a $\mathrm{pH}$ of 6.0 and heat-treated at $85^{\circ} \mathrm{C}$ for $10 \mathrm{~min}$, shelf-lives above 21 days are expected. Under the same heat-treatment condition, if the $\mathrm{pH}$ is reduced to 5.7, shelf-lives above 50 days are expected as a significant $\mathrm{pH}$ effect has been identified. These examples are based on calculations including realistic chilled supply-chain temperatures, i.e. including some retailer/consumer refrigerator temperatures at $10^{\circ} \mathrm{C}$. This incorporation is possible with probabilistic methods since they take multiple-value inputs into account.
\end{abstract}

\section{INTRODUCTION}

\subsection{Food safety context}

One of the food product categories that is expanding is the chilled food category. The chilled foods market consists of food products that are stored at refrigeration temperatures until consumption. The European chilled food sector showed a $50 \%$ increase to $€ 9.1$ billion from 1991-1996 and in 2005 the European market for chilled prepared foods had a turnover of $€ 10.6$ billion (Del Torre et al. 2004, Leatherhead Food International 2007). To ensure a high quality in terms of taste and aroma, the safety of refrigerated, processed food of extended durability (REPFEDs) relies on a combination of mild heat treatment and refrigerated storage, sometimes in combination with other hurdles such reduced $\mathrm{pH}$ and water activity. Shelf-life of REPFEDs is generally in a range of two/three up to five/six weeks as function of the process and formulation conditions.

In REPFEDs, non-proteolytic Clostridium botulinum, is considered as a serious hazard because of its ability to grow at temperatures as low as $3^{\circ} \mathrm{C}$ (Carlin et al. 2004, Notermans, Dufrenne, \& Lund
1990, Peck 1997). Non-proteolytic C. botulinum is an anaerobic Gram-positive sporeforming rodshaped bacterium, able to produce toxins that cause foodborne botulism. Foodborne botulism is rare, but severe intoxication can be caused by consumption of foods containing the neurotoxin produced by Clostridium botulinum. This neurotoxin is also called botulinum toxin or BoNT and is one of the most poisonous natural toxins known. The toxic dose of foodborne botulism is very low. Consumption of as little as $30 \mathrm{ng}$ of neurotoxin is sufficient to cause illness and even death (Lund \& Peck 2000, Odlaug \& Pflug 1978).

The aim of this study was to suggest combinations of heat-treatment and shelf-life which maximize product quality without compromising public health safety. To do so, an exposure assessment model incorporating the key elements of REPFEDs in term of process, formulation and supply-chain distributions, i.e. mild heat treatment $\left(<90^{\circ} \mathrm{C}\right.$ for $\left.10^{\prime}\right)$, mild acidic $\mathrm{pH}$ values (5.5 to 6.5), high water activity values $(>0.97)$, and chilled storage temperature (realistic values coming from supply-chain surveys), has been developed. Particular attention was paid to 
In Safety, reliability and risk analysis: theory, methods and applications. S. Martorell, C.G. Soares, J. Barnett (eds). 2009. Volume 3, pp 2295-2303. Publisher: CRC Press, Taylor and Francis Group, London.

the heat-treatment impact as this factor is one on which the food operator can rely on when setting the food safety control measures.

\subsection{Heat-treatment effect on non proteolytic $\mathrm{C}$. botulinum}

Heat treatments affect the outgrowth of spores of non-proteolytic $C$. botulinum in two ways: inactivation and injury.

It is generally agreed that a temperature of $90^{\circ} \mathrm{C}$ for $10 \mathrm{~min}$ will deliver a $6 \mathrm{D}$ inactivation of nonproteolytic $C$. botulinum and this is a commonly used performance standard for the heat processing of chilled foods (Gould 1999). The $z$ values used to calculate process equivalence differ in different guidelines and codes of practice, but for example the US-FDA refer to a $z$ value of $7 \mathrm{C}^{\circ}$ for temperatures below $90^{\circ} \mathrm{C}$ (U.S.Food \& Drug Administration 2001), which are the temperatures of concern in this present study.

In addition to this killing or 'cidal' effect and depending on the heat treatment applied, some spores remaining after the heat treatment may be injured. Due to this injury, the time for the spores to recover is prolonged and the length of the lag time is increased (Peck et al. 1995, Peck 1997). This injury heat-treatment effect depends also upon the recovery conditions such as temperature (chilled conditions), $\mathrm{pH}$ and water activity $\left(a_{\mathrm{w}}\right)$. If the shelf-life of the REPFED is short enough, it is biologically possible that the injured spores of $C$. botulinum have insufficient time to recover, germinate, multiply and potentially produce toxins.

When performing a risk assessment of REPFEDs, both heat-treatment effects, i.e. inactivation and injury, should be taken into account in the exposure assessment model as both contribute to significantly reduce the exposure level. In the following section, the methodology to combine the two heat-treatment effects is presented.

\section{METHODOLOGY}

\subsection{Combining thermal inactivation and thermal injury in an overall Degree of Protection}

The principle of the approach used to calculate the Degree of Protection (DoP) combining thermal inactivation effect and thermal injury effect is based on similar work previously reported in the literature (Hauschild 1982, Lund 1993, Schillinger, Geisen, \& Holzapfel 1996). Details are provided in Equations 1 to 4 .

$$
\mathrm{DoP}=\Delta \mathrm{R}+\mathrm{ThI}
$$

where, $\Delta \mathrm{R}$ is the log reduction due to thermal inactivation, and ThI the degree of protection due to thermal injury. Both terms can be expressed as the decimal logarithm of the reciprocal of a probability (Equations $2 \& 3)$.

$\Delta \mathrm{R}=\log (1 / \mathrm{Pr})$

$\mathrm{ThI}=\log (1 / \mathrm{Pi})$

where $\operatorname{Pr}$ is the probability that one spore survives the heat treatment, and $\mathrm{Pi}$ is the probability that lag time (recovery time) is shorter than the shelf-life (SL) as indicated in Equation 4.

$\mathrm{Pi}=$ Probability $\{\mathrm{Lag} \leq \mathrm{SL}\}$

When the exposure assessment model is built, the output can be presented in two ways.

The first is to present the Degree of Protection, including thermal inactivation and injury, for different conditions of process, formulation ( $\mathrm{pH}$ and $a_{\mathrm{w}}$ ) and chilled storage conditions at various shelf-lives.

The second is to choose a targeted Degree of Protection, and present the model output as a set of combinations of process, formulation, storage conditions and shelf-life which deliver this targeted DoP. This second output visualization could be compared to an iso-probability method, as DoP are derived from probability calculations, and these isoprobabilities could be a basis for future operational Guidelines or user-friendly tools.

It is the second approach which has been selected in this study. An overall degree of protection of 6 has been chosen as it is a reference value currently applied in food safety management, in the form of inactivation (Gould 1999).

To calculate $\Delta \mathrm{R}$, the widely-used Bigelow model has been applied (Bigelow 1921). To calculate ThI, a lag model has been developed, details are given in the following sections.

\subsection{Lag model development: data used}

322 data points from 15 different studies (Table 1) were incorporated in the model input data set. Time-to-toxin data were taken into account in the model as left-censored data, since these data are less conservative than time-to-growth determined by plate count method. Time-to-growth (turbidity) and time to gas production have been considered as close enough to the actual lag time to be kept in the model input list without being censored. This is based mainly on the fact that often, more than one tube was studied and the response kept in our analysis is based on the shortest time. However, this introduces uncertainty in the model output which should be considered before any interpretation (see Discussion section).

Also, right-censored observed data were taken into account, which extended the data collection to experiments which were stopped before any growth or toxin production were observed. From the 322 data points, 156 were non-censored and 166 censored. Both heat-treated and non-heat-treated data were taken into account to assess the impact of for- 
In Safety, reliability and risk analysis: theory, methods and applications. S. Martorell, C.G. Soares, J. Barnett (eds). 2009. Volume 3, pp 2295-2303. Publisher: CRC Press, Taylor and Francis Group, London. ISBN 978-0-415-48513-5

mulation and chilled storage conditions. From the 322 data points, 97 were heat-treated and 225 were not heat-treated.

Table 1. List of publications reviewed before including (at least partially) the data as model inputs

\begin{tabular}{cc}
\hline $\begin{array}{c}\text { Experimental me- } \\
\text { dium }\end{array}$ & References \\
\hline Beef stew & (Schmidt, Lechowich, \& Fo- \\
linazzo 1961) \\
Different medium \\
Eel and mackerel \\
Meat & (Smelt \& Rijke 1994) \\
Meat & (Eklund, Wieler, \& Poysky 1967) \\
Meat slurry & (Peck \& Fernandez 1995) \\
Potato, mushroom, & (Peck 1997) \\
cauliflower & (Elliott \& Schaffner 2001) \\
PYGS & (Graham, Mason, \& Peck 1996) \\
PYGS & (Stringer, Haque, \& Peck 1999) \\
PYGS, potato, & (Carlin et al. 2000) \\
broccoli & \\
Soya peptone broth & (Lawson, Adair, \& Cole 1992) \\
medium & (Emodi \& Lechowich 1969) \\
TPSY & (Lawson, Adair, \& Cole 1992) \\
Turkey & (Austin et al. 1998) \\
Vegetable & (Carlin \& Peck 1995) \\
Vegetable & (Stringer \& Peck 1997) \\
PYGS & (Notermans, Dufrenne, \& Lund \\
Meat & 1990) \\
Crabmeat and & (Solomon et al. 1977) \\
Broth &
\end{tabular}

1. Observed data are uncertain (several days or even weeks before two observations), consequently these data have been used as additional information/validation and not strictly as model inputs.

\subsection{Lag model development: model structure}

From the literature review on lag time and also on the more general predictive microbiology knowledge, several assumptions have been made to define the model structure:

$\checkmark$ the factors that influence the lag time include temperature (chilled storage temperature), $\mathrm{pH}$, $a_{\mathrm{w}}$, heat-treatment time and temperature;

$\checkmark$ the Gamma concept (Wijtzes et al. 1998, Zwietering 2002), widely employed to combine the effect of several factors on the growth rate, has been applied to the lag, considering an inversely proportional relationship between lag and growth rate, the Gamma concept is still relevant to combine the effect of several factors on lag;

$\checkmark$ the square root transformation has been chosen to stabilize the variance. The logarithm transformation is also a relevant and parsimonious (no need to add an extra parameter) method to stabilize the variance, but when dealing with numerical values such as 0 in the estimation process, the square root transformation is easier to implement.

The lag time model equations are detailed in Equation 5 to 12.

$$
\begin{aligned}
& \sqrt{\mathrm{Lag}} \sim \mathrm{N}\left(\sqrt{\mathrm{Lag} \_ \text {mean }}, \sigma\right) \\
& \sqrt{\mathrm{Lag} \_ \text {mean }}=\mathrm{a}_{1} \times \mathrm{f}_{11}(\mathrm{~T}) \times \mathrm{f}_{12}(\mathrm{pH}) \times \mathrm{f}_{13}\left(\mathrm{a}_{\mathrm{w}}\right) \times \mathrm{f}_{14}(\mathrm{HT}) \\
& \sqrt{\text { Lag_mean }}=\mathrm{a}_{2} \times \mathrm{f}_{21}(\mathrm{~T}) \times \mathrm{f}_{22}(\mathrm{pH}) \times \mathrm{f}_{23}(\mathrm{aw})
\end{aligned}
$$

Equation 6 is applied in presence of heattreatment, i.e. when the temperature is equal to or greater than $70^{\circ} \mathrm{C}$ (Elliott \& Schaffner 2001), Equation 7 is applied otherwise.

In Equations 6 and 7, functions $\mathrm{f}$ are defined as $f_{i j}(x) \geq 1$ in the domain of application/use of the model, to consider that the Lag_mean would be at its minimum if the optimal conditions were applied (ambient storage temperature, neutral $\mathrm{pH}$, maximum aw, heat-treatment at $70^{\circ} \mathrm{C}$ ). The model has been developed using data generated under different conditions, collected by different research teams, and unfortunately the 322 data set analyzed does not cover the whole range of factors in a systematic manner, including all relevant combinations. Because of the data gaps, and also due to uncertainties (e.g. on $\mathrm{pH}$ and $a_{\mathrm{w}}$ values), the model outputs have been analyzed from a statistical perspective and then, from a practical application and microbiological perspective.

From a statistical perspective, terms $\mathrm{f}_{11}$ and $\mathrm{f}_{21}$ are similar (relative effect of chilled storage temperature is the same in presence or absence of heat treatment). The terms $\mathrm{f}_{12}$ and $\mathrm{f}_{22}$ on one hand, and terms $\mathrm{f}_{13}$ and $\mathrm{f}_{23}$ on the other hand, are significantly different. This might reflect that the effect of $\mathrm{pH}$ (and $a_{\mathrm{w}}$ ) in the presence or absence of heat treatment, is different, but at this stage, this is only an assumption.

Effects attributed to the food matrix have already been reported in the literature but they have not been comprehensively analyzed and are not wellunderstood. As the general model structure chosen here is a Gamma concept structure, the matrix effect is only associated to two parameters, parameters $\mathrm{a}_{1}$ (Equation 6) and $\mathrm{a}_{2}$ (Equation 7). From a statistical perspective, the parameter $\mathrm{a}_{2}$ was significantly different when applied to data collected using broth, vegetable or meat; while the parameter $a_{1}$ was not significantly different. To facilitate the practical application, it has been decided to merge the effect of broth, vegetable and meat on the lag time, in the case of heat treatment (unique term $a_{1}$ in Equation 6).

The set of equations to describe storage temperature, $\mathrm{pH}, a_{\mathrm{w}}$ and heat treatment effect are provided in Equations 8-11

$\mathrm{f}_{11}(\mathrm{~T})$ and $\mathrm{f}_{21}(\mathrm{~T})=\left(\frac{(\mathrm{Topt}-\mathrm{Tmin})}{\mathrm{T}-\mathrm{Tmin}}\right)^{\mathrm{p} 1}$. 
In Safety, reliability and risk analysis: theory, methods and applications. S. Martorell, C.G. Soares, J. Barnett (eds). 2009. Volume 3, pp 2295-2303. Publisher: CRC Press, Taylor and Francis Group, London.

$$
\begin{aligned}
& \mathrm{f}_{12}(\mathrm{pH})=\left(\frac{(\mathrm{pHopt}-\mathrm{pHmin})}{\mathrm{pH}-\mathrm{pHmin}}\right)^{\mathrm{p} 12} \quad \mathrm{f}_{22}(\mathrm{pH})=\left(\frac{(\mathrm{pHopt}-\mathrm{pH} \text { min })}{\mathrm{pH}-\mathrm{pHmin}}\right)^{\mathrm{p} 22} \\
& \mathrm{f}_{13}\left(\mathrm{a}_{\mathrm{w}}\right)=\left(\frac{\left(a_{w} \mathrm{ppt}-a_{w} \min \right)}{a_{w}-a_{w} \min }\right)^{\mathrm{p} 13} \quad \mathrm{f}_{23}\left(\mathrm{a}_{\mathrm{w}}\right)=\left(\frac{\left(a_{w} \mathrm{ppt}-a_{w} \min \right)}{a_{w}-a_{w} \min }\right)^{\mathrm{p} 23} \\
& \mathrm{f}_{14}(\mathrm{HT})=\left(\mathrm{HTT}-\mathrm{HTT}_{\min }\right)^{\mathrm{p} 41} \times \mathrm{HT}_{-} \mathrm{t}^{\mathrm{p} 42}
\end{aligned}
$$

Finally, in order to assess realistic exposure level in the market place, when calculating $\mathrm{f}_{11}(\mathrm{~T})$ and feeding it in $\mathrm{P}_{\mathrm{i}}$ (Equation 4), realistic supply-chain chilled conditions were applied. In the illustration presented in the Results part (section 3.2), the US survey on domestic refrigerator temperatures (Food and Drug Administration 1999) was used.

\subsection{Statistical methods and software}

322 data were used to estimate the lag model, some of them are right-censored (the data recording was stopped before the lag finished) some of them are left-censored (experimental data corresponding to toxin production, meaning that the observed response is longer than the lag time). Despite a relatively large amount of data to solve the model, some additional expert opinion information was valuable. Also, even if the $\mathrm{pH}$ factor was often reported in the literature, sometimes it was not. In this latter case, the minimum-to-maximum range known for similar foods (Jay 1992) was used. Then, a Bayesian approach has been chosen for this flexibility when dealing with such a data set.

The Bayesian Markov Chain Monte Carlo procedure was run with the Winbugs package (version 1.4, Medical Research Council, UK). To check the convergence of the iteration process, visual analyses (history function and Gelman and Rubin diagnostic) of three independent chains were performed. 20,000 iterations were run, the first 10,000 iterations were eliminated (burning period). No convergence problems were detected.

To explore the consequence of heat-treatment (inactivation and injury) on the Degree of Protection and to suggest some process and formulation conditions which might deliver a 6-log Degree of Protection, a Monte Carlo simulation process was carried using Excel and @ Risk (Palisade Corporation, Newfield, USA). For each scenario 100,000 values were sampled by using the Latin Hypercube method.

\subsection{Model verification: graphical methods}

The model verification has been carried out using graphical methods. The correlation between parameters has been checked by analyzing scatter plots for all the combinations of parameters. Strictly speak- ing, a model can be valid even if there are high correlations between some parameters, but high correlated parameters lead to difficulties in interpreting the model outputs. No "high correlation" problems have been detected for the subset of equations applied to heat treatment effect, while for the subset of equations without heat treatment, this situation was more borderline. This might be a direct consequence of the data set used to run the model (different studies reported in literature, with some data gaps).

The second graphical method used to verify the model relevance, was to analyze the predicted versus observed values, and check if there was any bias or underlying structure. This was done also by analyzing the residual errors (predicted - observed values). No systematic bias or apparent structure has been detected.

\section{RESULTS}

\subsection{Lag model outputs: predicted versus observed values}

Observed values are plotted against predicted values, with the $90 \%$ credibility interval. Data have been collected at $75,80,85$ and $90^{\circ} \mathrm{C}$. At $90^{\circ} \mathrm{C}$, whatever the conditions of $\mathrm{pH}, a_{w}$ or storage temperature, the lag times reported were longer than 90 days. Results obtained at $75^{\circ} \mathrm{C}$ and $85^{\circ} \mathrm{C}$ are presented in Figures 1 to 4.

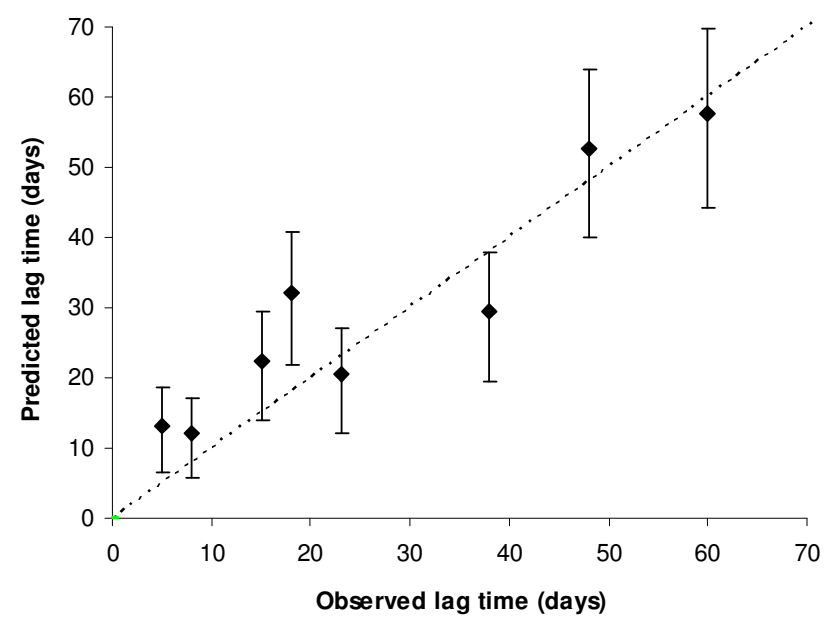

Figure 1: Lag time data points at $75^{\circ} \mathrm{C}$. The data at 60 days are censored (lag is longer). 
In Safety, reliability and risk analysis: theory, methods and applications. S. Martorell, C.G. Soares, J. Barnett (eds). 2009. Volume 3, pp 2295-2303. Publisher: CRC Press, Taylor and Francis Group, London. ISBN 978-0-415-48513-5

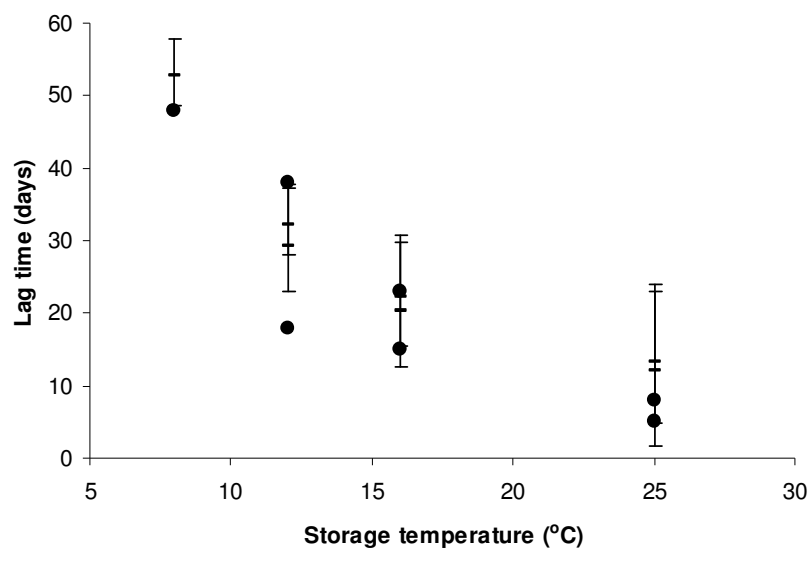

Figure 2: Observed (solid dots) and predicted (dashed dots with credible intervals) values of lag time versus storage temperature. The censored data at 60 days are not plotted.

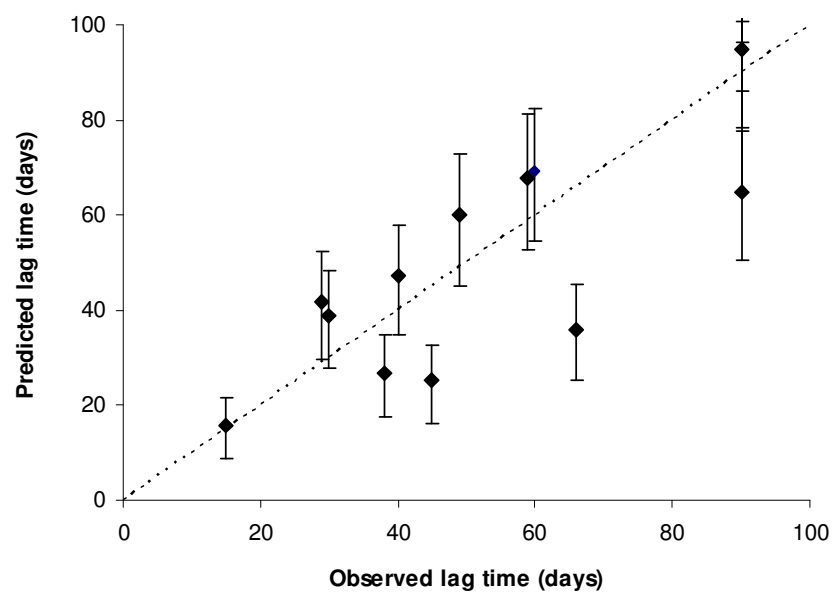

Figure 3: Lag time data points at $85^{\circ} \mathrm{C}$. The data at 60 and 90 days are censored (lag is longer).

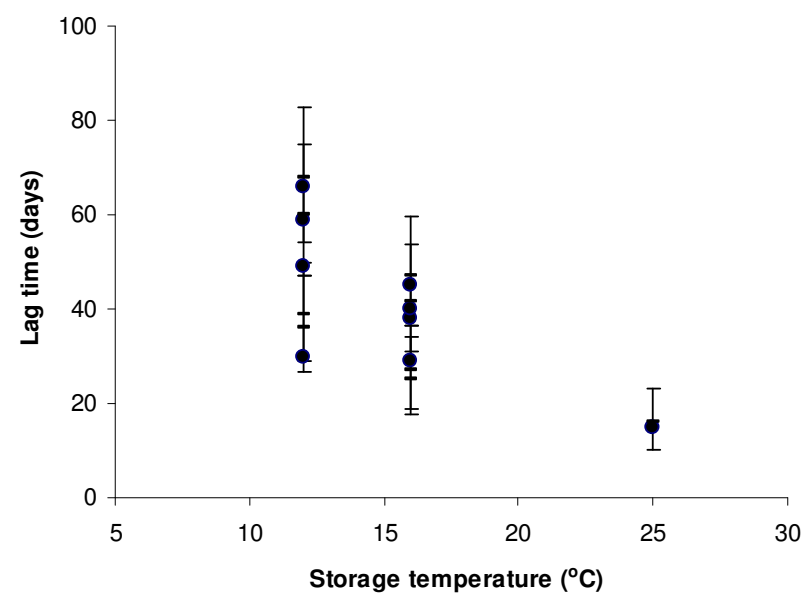

Figure 4: Observed (solid dots) and predicted (dashed dots with credible intervals) values of lag time versus storage temperature. The censored data at 60 and 90 days are not plotted.
At $85^{\circ} \mathrm{C}$, all the data showing relatively short lag times are actually collected at relatively high storage temperatures (Figure 4). A detailed analysis of censored data shows: i) with heat-treatment times of either $18 \mathrm{~min}$ or $23 \mathrm{~min}, \mathrm{pH} 6.5, a_{\mathrm{w}} 0.999$, lag times are longer than 60 days at storage temperature of 5 and $8^{\circ} \mathrm{C}$; also ii) in the same conditions but $\mathrm{pH} 6$, lag time was reported longer than 90 days; and finally iii) at $\mathrm{pH} 5.6$ lag time was longer than 90 days even at storage temperature of 12 or $16^{\circ} \mathrm{C}$ (Peck et al. 2006).

In conclusion, at $85^{\circ} \mathrm{C}$, conditions with $\mathrm{pH}$ between 5.5 and 6.0 and chilled temperatures $\left(\leq 10^{\circ} \mathrm{C}\right)$ seem key conditions to significantly extend the lag times. This set of conditions has been investigated further in the next section.

\subsection{Application of the Degree of Protection concept}

The Degree of Protection (DoP) concept can be compared to an iso-probability method, as DoP is derived from probability calculations. For example, there is the same probability $\left(1.10^{-6}\right)$ of having nonproteolytic $C$. botulinum surviving a heat treatment of $88^{\circ} \mathrm{C}$ for $10 \mathrm{~min}$, at $\mathrm{pH} 6.3$ and recovering within 30 days, as having non-proteolytic $C$. botulinum surviving a heat treatment of $84^{\circ} \mathrm{C}$ for $10 \mathrm{~min}$, at $\mathrm{pH} 5.7$ and recovering within 50 days (Figure 5). The chilled temperature conditions used to illustrate this approach are taken from the US survey (Food and Drug Administration 1999).

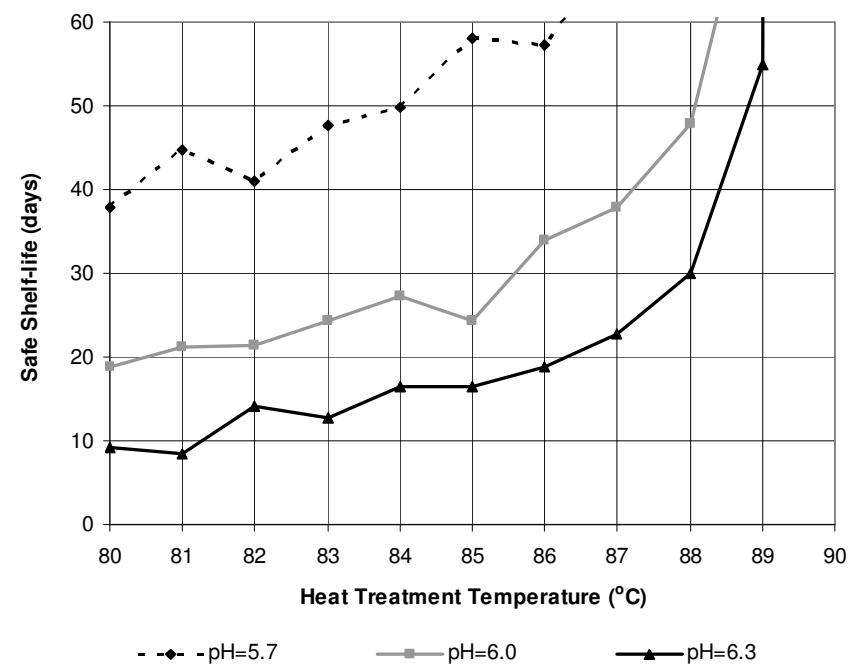

Figure 5: Combinations of heat-treatment temperatures (applied for $10 \mathrm{~min}$ ), $\mathrm{pH}$ and shelf-life which maximize product quality without compromising public health safety. Illustration of the concept with a Degree of Protection chosen as 6. 
In Safety, reliability and risk analysis: theory, methods and applications. S. Martorell, C.G. Soares, J. Barnett (eds). 2009. Volume 3, pp 2295-2303. Publisher: CRC Press, Taylor and Francis Group, London.

These results, although very encouraging from a risk management perspective in a food safety context, have to be interpreted with care, and validated before being applied at the operational level, for instance by challenge-testing.

\section{DISCUSSION}

In this paper we have described a model that predicts the effects of sub-' 90 for 10' heating on lag time of spores of non-proteolytic $C$. botulinum. The data used to generate the lag model, and predictions from the model show that significant lag times can be expected after heating at temperatures $>75^{\circ} \mathrm{C}$ and that additional inhibitory effects are afforded by intrinsic and extrinsic factors such as reduced $\mathrm{pH}, a_{\mathrm{w}}$ and storage at chill temperatures. The mechanism of sub-lethal injury and inhibition to psychrotrophic spore-forming bacteria such as non-proteolytic $C$. botulinum is not well-understood. For bacterial spore-formers in general, heat injury results in specific requirements for germination stimulants, optimum growth temperatures, nutrients and a higher sensitivity to growth inhibitors (Johnson \& Busta 1984). From studies showing improved recovery of heat-treated non-proteolytic $C$ botulinum spores using lysozyme in recovery media (Schaeffer \& Ionesco 1972) it is thought that damage to sporerelated lytic enzymes plays some role in some injury effects. Such effects are not as significant with spores of mesophilic (proteolytic) C. botulinum. It is likely that adverse effects other than damage to lytic enzymes in the spore may contribute to the increase in lag time observed in the studies involving heating non-proteolytic C. botulinum spores in sub-optimal growth conditions.

By combining this injury effect with more conventional, processing options, such as heating to deliver a $\log$ reduction in numbers, the Degree of Protection approach detailed in this paper, provides the ability to make much better use of combination preservation conditions that are less damaging for product quality but should still deliver the required level of safety. The importance of such interactions has been recognized for controlling mesophilic sporeformers in ambient-stable products. Braithwaite and Perigo (Braithwaite \& Perigo 1971) produced a set of contour plots where limiting $\mathrm{F}_{0}$ values were plotted against $a_{\mathrm{w}}$ and $\mathrm{pH}$, clearly showing combinations of conditions that may only require relatively mild heat treatments (e.g. $\mathrm{F}_{0}$ 0.3) to deliver ambient stability. The concept of taking account of destruction and injury was first described by Pivnick and Petrasovits (Pivnick \& Petrasovits 1973) in relation to safety of shelf-stable canned cured meats and developed further by Hauschild and Simonsen (Hauschild \& Simonsen 1985) to estimate the 'protection' of a food based on probability of spores surviving the heat process, overcoming inhibition, growing out and producing toxin. Hauschild and Simonsen (1985) expressed this 'protection' by deriving a safety unit (SU), a quotient analogous to the log of reciprocal of probability of toxin production multiplied by incidence of spores in raw product. This quotient was based on industrial experience with commercial products that had a safe history of use because experimental work was not sufficiently reliable to assess safety.

In our study, to recalculate the combination of heat-treatment temperatures, $\mathrm{pH}$ and shelf-life which maximize product quality without compromising public health safety (Figure 5), the US Audit data (Food and Drug Administration 1999) have been used. Consequently, some retailer/consumer refrigerator temperatures at $10^{\circ} \mathrm{C}$, have been incorporated in the analysis. This incorporation is possible with probabilistic methods since they take multiple-value inputs into account. Probabilistic modeling techniques have been already applied to spore-forming bacteria (Barker et al. 2005, Membré et al. 2006) and their values for microbiological risk assessment applied to food safety have been already emphasized (Albert, Pouillot, \& Denis 2005, Gonzalez-Martinez, Corradini, \& Peleg 2003, Vose 1998). For chilled products, they are particularly valuable as they allow the integration of realistic, complex, supply-chain inputs (Nauta 2001, Nauta et al. 2003, Rosset et al. 2004).

Definitively, the Degree of Protection approach would allow shelf-lives and/or heat-treatment to be set that give new food management design windows. For example, with a product having a $\mathrm{pH}$ of 5.7 and heat-treated at $85^{\circ} \mathrm{C}$ for $10 \mathrm{~min}$, shelf-lives (targeting non-proteolytic Clostridium botulinum) of 55 days are expected. This is significantly longer than the common shelf-lives of REPFEDs. However, there are a number of data gaps in the data set used to produce the model. The data used were taken from a limited number of published literature studies. Also, uncertainties have been generated when estimating lag time from first observed time to growth (turbidity or gas production). In some cases, we have assumed values for factors (e.g. $\mathrm{pH}$ and $a_{w}$ ) that may influence lag time where these were not reported in the studies used. We intend to fill some of these gaps with further work. Even though these additional data should improve the current model and improve model predictions, it is important that full validation of any predicted effects is made in real foods before they are launched in the market. Faille et al. (Faille et al. 1997) emphasized the importance of testing relevant strains in the food of concern because of the different responses that can be seen in other systems, such as buffer.

The Degree of Protection model proposed in this paper falls within the framework of risk assessment 
In Safety, reliability and risk analysis: theory, methods and applications. S. Martorell, C.G. Soares, J. Barnett (eds). 2009. Volume 3, pp 2295-2303. Publisher: CRC Press, Taylor and Francis Group, London. ISBN 978-0-415-48513-5

(exposure assessment step) and more generally within the new food risk management approaches (CAC (Codex Alimentarius Commission) 2004, CCFH (Codex Committee on Food Hygiene) 2005, CCGP (Codex Committee on General Principles) 2005). The Food Safety Objective (FSO) signifies a maximum hazard level at consumption that still constitutes a product that is safe for consumption and a Performance Objective (PO) is similar to the FSO but is applied earlier in the farm-to-fork food supply chain.

The Performance Criterion (PC) refers to the effect in frequency and/or concentration of a hazard in a food that must be achieved by the application of one or more control measures to provide or contribute to a PO or an FSO. The 6-log Degree of Protection defined here can be considered equivalent to a $6 D$ inactivation, a standard PC used to assure safety of chilled foods; and consequently, the approach described in this paper is a means of articulating the FSO, PO and PC with practical and easy-to-beimplemented food safety control measures. A similar attempt has been demonstrated recently with thermal inactivation of Salmonella in poultry meat (Membré, Bassett, \& Gorris 2007).

\section{REFERENCES}

Albert, I., Pouillot, R., \& Denis, J. B. 2005. Stochastically modeling Listeria monocytogenes growth in farm tank milk. Risk Analysis 25: 1171-1185.

Austin, J. W., Dodds, K. L., Blanchfield, B., \& Farber, J. M. 1998. Growth and toxin production by Clostridium botulinum on inoculated fresh-cut packaged vegetables. Journal of Food Protection 61: 324-328.

Barker, G. C., Malakar, P. K., Del Torre, M., Stecchini, M. L., \& Peck, M. W. 2005. Probabilistic representation of the exposure of consumers to Clostridium botulinum neurotoxin in a minimally processed potato product. International Journal of Food Microbiology 100: 345-357.

Bigelow, W. D. 1921. The logarithmic nature of thermal death time curves. Journal of Infectious Diseases 29: 528-236.

Braithwaite, P. J. \& Perigo, J. A. 1971. The influence of of pH, water activity and recovery temperature on the resistance and outgrowth of Bacillus spores. In A. M. Barker, G. W. Gould, \& F. A. Skinner, eds. (eds) Spore research. London. Academic Press.

CAC (Codex Alimentarius Commission) 2004. Procedural Manual, 14th edn. Joint FAO/WHO Food Standards Programme, CAC Secretariat.

Carlin, F., Broussolle, V., Perelle, S., Litman, S., \& Fach, P. 2004. Prevalence of Clostridium botulinum in food raw materials used in REPFED manufactured in France. International Journal of Food Microbiology 91: 141-145.

Carlin, F., Girardin, H., Peck, M. W., Stringer, S. C., Barker, G. C., Martinez, A., Fernandez, A., Fernandez, P., Waites, W. M., Movahedi, S., van Leusden, F., Nauta, M., Moezelaar, R., Del Torre, M., \& Litman, S. 2000. Research on factors allowing a risk assessment of spore-forming pathogenic bacteria in cooked chilled foods containing vegetables: a FAIR collaborative project. International Journal of Food Microbiology 60: 117-135.

Carlin, F. \& Peck, M. W. 1995. Growth and toxin production by non-proteolytic and proteolytic Clostridium botulinum in cooked vegetables. Letters in Applied Microbiology 20: 152156.

Carlin, F. \& Peck, M. W. 1996. Growth of and toxin production by nonproteolytic Clostridium botulinum in cooked puréed vegetables at refrigeration temperatures. Applied and Environmental Microbiology 62: 3069-3072.

CCFH (Codex Committee on Food Hygiene) 2005. Proposed Draft Principles and Guidelines for the Conduct of Microbiological Risk Management. In Report of the 37th Session of the Codex Committee on Food Hygiene, Buenos Aires, Argentina, 14 - 19 March 2005. ALINORM 05/28/13, Appendix III.

CCGP (Codex Committee on General Principles) 2005. Proposed draft working principles for risk analysis for food safety. In Report of the 21st Session of the Codex Committee on General Principles, Paris, France, 11-15 April 2005. ALINORM 05/28/33A.

Del Torre, M., Stecchini, M. L., Braconnier, A., \& Peck, M. W. 2004. Prevalence of Clostridium species and behaviour of Clostridium botulinum in gnocchi, a REPFED of Italian origin. International Journal of Food Microbiology 96: 115131.

Eklund, M. W., Wieler, D. I., \& Poysky, F. T. 1967. Outgrowth and toxin production of nonproteolytic Type B Clostridium botulinum at 3.3 to $5.6^{\circ} \mathrm{C}$. Journal of Bacteriology 93: 14611462.

Elliott, P. H. \& Schaffner, D. W. 2001. Germination, growth and toxin production of nonproteolytic Clostridium botulinum as affected by multiple barriers. Journal of Food Science 66: 575-579.

Emodi, A. S. \& Lechowich, R. V. 1969. Low temperature growth of Type E Clostridium botulinum spores. 2. Effects of solutes and incubation temperature. Journal of Food Science 34: 82-87.

Faille, C., Lebret, V., Gavini, F., \& Maingonnat, J.-F. 1997. Injury and lethality of heat treatment of Bacillus cereus spores suspended in buffer and in poultry meat. Journal of Food Protection 60: 544-547.

Food and Drug Administration 1999. 1999 U.S. Cold Temperature Evaluation Design and Study Summary. Available at http://www.foodrisk.org/exclusives/audits/. Accessed on 244-2008.

Gonzalez-Martinez, C., Corradini, M. G., \& Peleg, M. 2003. Probabilistic models of food microbial safety and nutritional quality. Journal of Food Engineering 56: 135-142.

Gould, G. W. 1999. Sous vide foods: conclusion of an ECFF Botulinum Working Party. Food Control 10: 47-51.

Graham, A. F., Mason, D. R., \& Peck, M. W. 1996. Predictive model of the effect of temperature, $\mathrm{pH}$ and sodium chloride on growth from spores of non-proteolytic Clostridium botulinum. International Journal of Food Microbiology 31: 69-85.

Hauschild, A. H. W. 1982. Assessment of botulism hazards from cured meat products. Food Technology 36: 95-104.

Hauschild, A. H. W. \& Simonsen, B. 1985. Safety of shelfstable canned cured meats. Journal of Food Protection 48: 997-1009.

Jay, J. M. 1992. Intrinsic and extrinsic parameters of foods that affect microbial growth - intrinsic parameters. In J. M. Jay, 
In Safety, reliability and risk analysis: theory, methods and applications. S. Martorell, C.G. Soares, J. Barnett (eds). 2009. Volume 3, pp 2295-2303. Publisher: CRC Press, Taylor and Francis Group, London.

ed. (eds) Modern Food Microbiology . 38-52. New York. Chapman \& Hall.

Johnson, K. M. \& Busta, F. F. 1984. Detection and enumeration of injured bacterial spores in processed foods. In M. H. E. Andrew \& A. D. Russell, eds. (eds) The revival of injured microorganisms . 241-256. London. Academic Press.

Lawson, S. F., Adair, C., \& Cole, M. B. 1992. Growth of non proteolytic Clostridium botulinum at chill temperatures: A predictive model for the effect of temperature and salt concentration on toxin formation. Unpublished.

Leatherhead Food International 2007. CFA Chilled Food Association - Chilled foods market. Available at http://www.chilledfood.org/content/guidance.asp. Accessed on 1-10-2007.

Lund, B. M. 1993. Quantification of factors affecting the probability of development of pathogenic bacteria, in particular Clostridium botulinum, in foods. Journal of Industrial Microbiology 12: 144-155.

Lund, B. M. \& Peck, M. W. 2000. Clostridium botulinum. In B. M. Lund, T. C. Baird-Parker, \& G. W. Gould, eds. (eds) The Microbiological Safety and Quality of Food . 10571109. Gaithersburg, Maryland. Aspen.

Membré, J.-M., Amézquita, A., Bassett, J., Giavedoni, P., Blackburn, C. d. W., \& Gorris, L. G. M. 2006. A probabilistic modeling approach in thermal inactivation: Estimation of postprocess Bacillus cereus spore prevalence and concentration. Journal of Food Protection 69: 118-129.

Membré, J.-M., Bassett, J., \& Gorris, L. G. M. 2007. Applying the Food Safety Objective and related standards to thermal inactivation of Salmonella in poultry meat. Journal of Food Protection 70: 2036-2044.

Nauta, M. J. 2001. A modular process risk model structure for quantitative microbiological risk assessment and its application in an exposure assessment of Bacillus cereus in REPFED. Available at http://www.rivm.nl/bibliotheek/rapporten/149106007.html. Accessed on 7-10-2006.

Nauta, M. J., Litman, S., Barker, G. C., \& Carlin, F. 2003. A retail and consumer phase model for exposure assessment of Bacillus cereus. International Journal of Food Microbiology 83: 205-218.

Notermans, S., Dufrenne, J., \& Lund, B. M. 1990. Botulism risk of refrigerated, processed foods of extended durability. Journal of Food Protection 53: 1020-1024.

Odlaug, T. E. \& Pflug, I. J. 1978. Clostridium botulinum and acid foods. Journal of Food Protection 41: 566-573.

Peck, M. W. 1997. Clostridium botulinum and the safety of refrigerated processed foods of extended durability. Trends in Food Science \& Technology 8: 186-192.

Peck, M. W., Evans, R. I., Fairbairn, D. A., Hartley, M. G., \& Russel, N. J. 1995. Effect of sporulation temperature on some properties of spores of non-proteolytic Clostridium botulinum. International Journal of Food Microbiology 28: 289-297.

Peck, M. W. \& Fernandez, P. S. 1995. Effect of lysozyme concentration, heating at $90^{\circ} \mathrm{C}$, and then incubation at chilled temperatures on growth from spores of non-proteolytic Clostridium botulinum. Letters in Applied Microbiology 21: 5054.

Peck, M. W., Goodburn, K. E., Betts, R. P., \& Stringer S.C. 2006. Clostridium botulinum in vacuum packed (VP) and modified atmosphere packed (MAP) chilled foods. Available at
http://www.ifr.ac.uk/science/programme/S2/Final_project_r eport0707.pdf. Accessed on 4-2-2008.

Pivnick, H. \& Petrasovits, A. "A rationale for the safety of canned shelf-stable cured meats: protection $=$ destruction + inhibition", Paris, France, pp. 1086-1094.

Rosset, P., Cornu, M., Noel, V., Morelli, E., \& Poumeyrol, G. 2004. Time-temperature profiles of chilled ready-to-eat foods in school catering and probabilistic analysis of Listeria monocytogenes growth. International Journal of Food Microbiology 96: 49-59.

Schaeffer, P. \& Ionesco, H. 1972. Germination lzP-dépendante des spores de Clostridium botulinum type C. Comptes Rendus de l' Academie des Sciences 275D: 2175-2177.

Schillinger, U., Geisen, R., \& Holzapfel, W. H. 1996. Potential of antagonistic microorganisms and bacteriocins for the biological preservation of foods. Trends in Food Science \& Technology 7: 158-164.

Schmidt, C. F., Lechowich, R. V., \& Folinazzo, J. F. 1961. Growth and toxin production by Type E Clostridium botulinum below $40^{\circ} \mathrm{F}$. Journal of Food Science 26: 626630.

Smelt, J. P. P. M. \& Rijke, A. G. F. 1994. Assessment of the botulinum risk of vacuum-packed hot-smoked fish as manufactured for and sold by Homann, dissen. Unpublished.

Solomon, H. M., Lynt, R. K., Lilly, T., \& Kautter, D. A. 1977. Effect of low temperatures on growth of Clostridium botulinum spores in meat of blue crab. Journal of Food Protection 40: 5-7.

Stringer, S. C., Haque, N., \& Peck, M. W. 1999. Growth from spores of nonproteolytic Clostridium botulinum in heattreated vegetable juice. Applied and Environmental Microbiology 65: 2136-2142.

Stringer, S. C. \& Peck, M. W. 1997. Combinations of heat treatment and sodium chloride that prevent growth from spores of nonproteolytic Clostridium botulinum. Journal of Food Protection 60: 1553-1559.

U.S.Food \& Drug Administration 2001. Fish and fisheries products hazards and controls guidance. Available at http://www.cfsan.fda.gov/ comm/haccp4.html. Accessed on 30-1-2008.

Vose, D. J. 1998. The application of quantitative risk assessment to microbial food safety. Journal of Food Protection 61: 640-648.

Wijtzes, T., Van't Riet, K., Huis in't Veld, J. H. J., \& Zwietering, M. H. 1998. A decision support system for the prediction of microbial food safety and food quality. International Journal of Food Microbiology 42: 79-90.

Zwietering, M. H. 2002. Quantification of microbial quality and safety in minimally processed foods. International Dairy Journal 12: 263-271. 